\title{
PEMBUATAN DAN KARAKTERISASI ARANG AKTIF DARI BATANG LIMBAH TANAMAN GUMITIR DENGAN AKTIVATOR $\mathbf{Z n C l}_{2}$
}

\author{
E. Sahara*, D. E. Permatasaari, I W. Suarsa \\ Jurusan Kimia FMIPA Universitas Udayana, Bukit Jimbaran, Bali \\ *Email: emmy_sahara@unud.ac.id
}

\begin{abstract}
ABSTRAK
Limbah pertanian batang tanaman gumitir dapat digunakan sebagai bahan pembuatan arang aktif. Penelitian sebelumnya menyatakan bahwa aktivasi terhadap arang dari batang tanaman ini dengan asam fosfat $\left(\mathrm{H}_{3} \mathrm{PO}_{4}\right)$ dan $\mathrm{NaOH}$ menghasilkan arang aktif yang memenuhi standar SNI 06-3730-1995 tentang arang aktif teknis.Tujuan dari penelitian ini adalah untuk membuat dan mengkarakterisasi arang aktif dari batang tanaman gumitir yang dikarbonisasi pada suhu $300^{\circ} \mathrm{C}$ selama 90 menit dengan aktivator $\mathrm{ZnCl}_{2}$. Aktivasi dilakukan dengan penambahan $\mathrm{ZnCl}_{2}$ ke arang gumitir dengan berbagai perbandingan mol. Hasil penelitian menunjukkan bahwa penambahan sebanyak $0,1 \mathrm{~mol} \mathrm{ZnCl}_{2}$ terhadap 1 gram arang menghasilkan arang aktif yang memenuhi standar SNI tersebut, dimana diperoleh kadar air 5,00\%, kadar abu 8,33\%, kadar zat mudah menguap pada pemanasan $950^{\circ} \mathrm{C}$ sebesar 7,36\%, kadar karbon $79,30 \%$, daya serap terhadap iod sebesar 788,1271mg/g, daya serap terhadap metilen biru sebesar $260,7917 \mathrm{mg} / \mathrm{g}$, serta mempunyai luas permukaan sebesar $677,6270 \mathrm{~m}^{2} / \mathrm{gdan}$ keasaman permukaan sebesar $0,3396 \mathrm{mmol} / \mathrm{gram}$. Analisis gugus fungsi terhadap arang aktif ini menunnjukkan adanya gugus-gugus $\mathrm{O}-\mathrm{H}, \mathrm{COOH}, \mathrm{C}-\mathrm{O}$ aldehid, $\mathrm{C}-\mathrm{C}$ alkuna dan $\mathrm{C}-\mathrm{H}$.
\end{abstract}

Kata kunci: arang aktif, batang gumitir, karakterisasi, $\mathrm{ZnCl}_{2}$

\begin{abstract}
The agricultural waste of gumitir plants stem can be used as an ingredient in producing an activated carbon. Some researchers have reported that the additions of phosphoric acid and $\mathrm{NaOH}$ as chemical activators have resulted in an activated carbon that met the SNI (Indonesian National Standard) 06-3730-1995 about technical activated carbon. The purpose of this study was to produce and characterize the activated carbon from the stem of gumitir plants carbonized at $300^{\circ} \mathrm{C}$ for 90 minutes with the use of $\mathrm{ZnCl}_{2}$ as the activator. The activation was carried out by adding $\mathrm{ZnCl}_{2}$ to an amount of carbon in various mole ratios. The characteristics of the activated carbon obtained were compared to the SNI. It was evident that the addition of $0.1 \mathrm{~mole}$ of $\mathrm{ZnCl}_{2}$ to 1 gram of the carbon produced an activated carbon that met the SNI standard, namely, water content of 5.00\%, as content of $8.33 \%$, volatile content of $950^{\circ} \mathrm{C}$ of heating of $7.36 \%$, carbon content of $79,30 \%$, iodine absorption capacity of $788.1271 \mathrm{mg} / \mathrm{g}$, and methylene blue absorption capacity of $260.7917 \mathrm{mg} / \mathrm{g}$. The surface area and surfae acidity of this carbon was of $677,6270 \mathrm{mg}^{2} / \mathrm{g}$ and $0.3396 \mathrm{mmol} / \mathrm{g}$, respectively. The functional group analysis of this activated carbon showed the presence of $\mathrm{O}-\mathrm{H}, \mathrm{COOH}, \mathrm{C}-\mathrm{O}$ aldehyde, alkaline $\mathrm{C}-\mathrm{C}$ and $\mathrm{C}$ H groups.
\end{abstract}

Keywords: activated carbon, characterization, marigold stem bark, $\mathrm{ZnCl}_{2}$

\section{PENDAHULUAN}

Arang aktif adalah suatu padatan yang bahan dasarnya karbon berpori dengan kandungan karbon sebesar 85-95\%. Arang aktif memiliki luas permukaan sangat tinggi yaitu di atas $600 \mathrm{~m}^{2} / \mathrm{gram}$. Luas permukaan yang sangat besar ini disebabkan oleh adanya struktur berpori sehingga arang aktif memiliki sifat sebagai adsorben. Arang aktif dapat menyerap gas dan senyawa-senyawa kimia tertentu karena besarnya volume pori-pori dan luas permukaannya (Rasdiansyah, 2014). Arang aktif mempunyai banyak manfaat diantaranya sebagai pembersih air, pengolahan limbah cair, pemurni gas, pemurni minyak kelapa, farmasi, kimia, dan dalam bidang industri. Contoh dalam bidang industri yaitu pada industri obat-obatan, makanan, minuman, pengolahan air atau penjernihan air dan lainlain (Cooney, 1980). 
Pembuatan arang aktif dimulai dari proses karbonisasi. Kemudian, arang yang terbentuk diubah menjadi arang aktif melalui proses aktivasi. Aktivasi arang terdiri dari dua metode utama anatara laindengan cara aktivasi fisik (physical activation) dan cara aktivasi kimiawi (chemical activation). Aktivasi fisik biasanya terdiri dari dua tahap. Tahapan pertama merupakan karbonisasi bahan dasar dengan pemanasan pada suhu sekitar $700^{\circ} \mathrm{C}$ yang dilanjutkan dengan tahap berikutnya, yaitu mengalirkan uap karbon dioksida atau pemanasan pada suhu $800-1000^{\circ} \mathrm{C}$ (Jamilatun et al, 2014). Aktivasi secara kimiawi dapat dilakukan dengan menambahkan bahan-bahan kimia sebagai aktivator. Pemilihan jenis aktivator akan berpengaruh terhadap kualitaskarbon aktif. Pada penelitian-penelitian sebelumnya aktivator kimia yang digunakan berupa asam, basa dan garam atau $\mathrm{KOH}$, $\mathrm{H}_{3} \mathrm{PO}_{4}$ dan $\mathrm{ZnCl}_{2}$ (Pambayun, 2013).

Karbonisasi limbah batang gumitir yang dilakukan pada suhu $300^{\circ} \mathrm{C}$ selama 90 menit telah dilaporkan menghasilkan arang aktif yang memenuhi standar SNI (Siaka dkk, 2016) yaitu dengan kadar air sebesar 4,00 \pm $0,00 \%$; kadar zat mudah menguap 6,58 \pm $0,07 \%$; kadar abu $4,34 \pm 1,22 \%$; daya serap terhadap $\mathrm{I}_{2} 631,0935 \pm 0,00 \mathrm{mg} / \mathrm{g}$; daya serap terhadap metilen biru $131,34 \pm 1,7 \mathrm{mg} / \mathrm{g}$ dan kadar karbon sebesar $85,44 \%$. Aktivasi asam fosfat $\left(\mathrm{H}_{3} \mathrm{PO}_{4}\right) 15 \%$ (Sahara dkk, 2017) dan dengan $\mathrm{NaOH}$ telah dilaporkan menghasilkan arang aktif yang memenuhi standard SNI 063730-1995 mengenai arang aktif teknis (Sahara dkk, 2017). Arang aktif yang berkualitas baik memiliki kadar air maksimal $15 \%$, kadar zat mudah menguap maksimal 25\%, kadar abu maksimal 10\% dan kadar karbon minimal 65\%, Daya serap arang aktif terhadap $\mathrm{I}_{2}$ minimal sebesar $750 \mathrm{mg} / \mathrm{g}$ dan daya serap terhadap metilen biru minimal $120 \mathrm{mg} / \mathrm{g}$ (SNI, 1995). Arang aktif yang telah diaktivasi dengan $\mathrm{H}_{3} \mathrm{PO}_{4}$ dan $\mathrm{NaOH}$ di atas, menunjukkan daya adsorpsi yang baik terhadap logam $\mathrm{Pb}$ dan $\mathrm{Cr}$ (Putri, 2017) serta $\mathrm{Cu}$ dan Cd (Kartini, 2017). Daya adsorpsi arang aktif ini jauh lebih baik dari daya adsorpsi arang tanpa aktivasi (Putri, 2017 dan Kartini, 2017).

Penelitian sebelumnya tentang arang aktif dengan aktivator $\mathrm{ZnCl}_{2}$ sudah banyak dilakukan. Laporan mengenai arang aktif dari ampas bubuk kopi yang diaktivasi dengan $\mathrm{ZnCl}_{2}$ menunjukkan bahwa temperatur, konsentrasi $\mathrm{ZnCl}_{2}$ dan rasio berat $\mathrm{ZnCl}_{2}$ dengan karbon aktif sangat berpengaruh terhadap daya serap iod (Radiansyah, 2014). Penelitian lainnya oleh Esterlita (2015), menunjukkan bahwa aktivator terbaik untuk aktivasi arang dari pelepah aren adalah $\mathrm{ZnCl}_{2}$ dan $\mathrm{H}_{3} \mathrm{PO}_{4}$, dibandingkan dengan aktivator $\mathrm{KOH}$.

Sampai sejauh ini aktivasi arang dari batang limbah tanaman gumitir sudah dilakukan dengan $\mathrm{H}_{3} \mathrm{PO}_{4}$ dan $\mathrm{NaOH}$ saja. Berdasarkan uraian di atas, maka dilakukan penelitian tentang pembuatan dan karakterisasi arang aktif dari batang limbah tanaman gumitir dengan aktivator $\mathrm{ZnCl}_{2}$.

\section{MATERI DAN METODE}

\section{Bahan}

Bahan-bahan yang digunakan dalam penelitian ini adalah limbah batang tanaman gumitir yang diperoleh dari Perkebunan Bali gumitir di Daerah Mayungan, BaturitiTabanan, $\mathrm{I}_{2}, \quad \mathrm{Na}_{2} \mathrm{~S}_{2} \mathrm{O}_{3} .5 \mathrm{H}_{2} \mathrm{O}, \quad \mathrm{ZnCl}_{2}, \quad \mathrm{KI}$, $\mathrm{K}_{2} \mathrm{Cr}_{2} \mathrm{O}_{7}$, metilen biru, amilum, aquades, kertas saring Whatman no.12, tissue.

\section{Peralatan}

Tanur, mortar, ayakan $100 \mu \mathrm{m}-200 \mu \mathrm{m}$, gelas beaker, gelas ukur, $\mathrm{pH}$ meter, timbangan analitik, cawan porselin, oven, desikator, labu erlenmeyer, pipet volume, pipet mikro, buret, statif, batang pengaduk, pengaduk magnetik, corong, hotplate, botol semprot, filler dan alat intrumen spektrofotometer UV-Vis dan Spektrofotometer Inframerah.

\section{Cara Kerja \\ Penyiapan Bahan}

Sampel batang tanaman gumitir dicuci dengan air kran, kemudian dibilas dengan aquades. Sampel kemudian dipotong kecil kecil dan dikeringkan dalam oven pada suhu $105^{\circ} \mathrm{C}$ hingga massa konstan.

\section{Karbonisasi Batang Gumitir Menjadi Arang}

Sebanyak 300 g sampel kering dikarbonisasi dalam tanur pada suhu $300^{\circ} \mathrm{C}$ dengan waktu 90 menit. Arang yang terbentuk ditimbang dan ditentukan persentase rendemennya. Selanjutnya arang digerus dan diayak menggunakan ayakan $100 \mu \mathrm{m}-200$ $\mu \mathrm{m}$. 


\section{Aktivasi Arang}

Ke dalam 5 buah gelas beaker dimasukkan masing-masing $12 \mathrm{~g}$ arang hasil karbonisasi. Lalu ditambahkan $200 \mathrm{~mL}$ larutan $\mathrm{ZnCl}_{2}$ dengan konsentrasi 0,$1 ; 0,25 ; 0,5 ; 1$; dan 1,5 $\mathrm{M}$, sehingga diperoleh perbandingan antara massa arang dan mol $\mathrm{ZnCl}_{2}$ sebagai berikut: $1: 0,02 ; 1: 0,05 ; 1: 0,1 ; 1: 0,2 ; 1$ : 0,3 atau perbandingan massa sebagai berikut: (1: 20,4472); (1: 13,6135); (1: 6,8157); (1: 3,4079); (1 : 1,3631). Campuran kemudian didiamkan selama 24 jam lalu disaring dan dibilas dengan aquades hingga $\mathrm{pH}$ netral. Arang kemudian dipanaskan di dalam tanur pada suhu $900^{\circ} \mathrm{C}$ selama 1 jam. Arang aktif yang terbentuk kemudian didinginkan hingga mencapai suhu ruangan dan ditimbang. Proses aktivasi diulang sebanyak 3 kali dan ditentukan persentase rendemennya.

\section{Karakterisasi Arang Aktif Penentuan Kadar Air}

Sebanyak $1 \mathrm{~g}$ arang aktif ditempatkan dalam cawan porselin yang telah diketahui massanya lalu dikeringkan dalam oven pada suhu $105^{\circ} \mathrm{C}$ hingga diperoleh massa konstan, kemudian didinginkan dalam desikator.

\section{Kadar Zat Mudah Menguap}

Arang aktif kering dipanaskan dalam tanur pada suhu $900^{\circ} \mathrm{C}$ selama 15 menit, kemudian didinginkan dalam desikator dan selanjutnya ditimbang.

\section{Kadar Abu Total}

Sebanyak $1 \mathrm{~g}$ arang aktif diletakkan di dalam cawan porselin, dipanaskan dalam oven pada suhu $105^{\circ} \mathrm{C}$ sampai diperoleh massa konstan. Sampel dalam cawan lalu dimasukkan ke dalam tanur dan diabukan pada suhu $650^{\circ} \mathrm{C}$ selama 4 jam, lalu didinginkan dalam desikator, selanjutnya ditimbang.

\section{Kadar Karbon Terikat}

Kadar karbon terikat dalam arang aktif adalah hasil dari proses pengarangan selain abu, air dan zat-zat yang mudah menguap.

\section{Daya Serap Terhadap Iod}

Sebanyak $1 \mathrm{~g}$ arang aktif dimasukkan ke dalam labu erlenmeyer, kemudian ditambahkan $25 \mathrm{~mL}$ larutan iodium $0,125 \mathrm{M}$. Larutan diaduk selama 15 menit lalu erlenmeyer ditutup dan disimpan ditempat yang gelap selama 2 jam. Larutan kemudian disaring, lalu filtratnya dipipet $10 \mathrm{~mL}$, dimasukkan ke dalam labu erlenmeyer yang bersih dan dititrasi dengan larutan $\mathrm{Na}_{2} \mathrm{~S}_{2} \mathrm{O}_{3} 0,1$ $\mathrm{M}$ hingga larutan berwarna kuning muda. Sebanyak $1 \mathrm{~mL}$ indikator amilum ditambahkan ke dalam larutan dan titrasi dilanjutkan sampai warna biru tepat hilang. Volume larutan $\mathrm{Na}_{2} \mathrm{~S}_{2} \mathrm{O}_{3}$ yang digunakan dicatat dan dihitung daya serap arang aktif terhadap iodin dalam $\mathrm{mg} / \mathrm{g}$.

\section{Daya Serap Terhadap Metilen Biru}

Dibuat kurva kalibrasi larutan metilen biru dengan konsentrasi 0, 2, 3, 4, 6, dan 8 $\mathrm{mg} / \mathrm{L}$. Kurva yang diperoleh digunakan untuk menentukan konsentrasi metilen biru sisa sehingga metilen biru yang diserap oleh arang aktif dapat diketahui. Sebanyak $1 \mathrm{~g}$ arang aktif dimasukkan ke dalam gelas beaker dan ditambahkan $200 \mathrm{~mL}$ larutan metilen biru $1000 \mathrm{mg} / \mathrm{L}$, diaduk dengan pengaduk magnet selama 30 menit. Larutan disaring dengan kertas saring Whatman no. 12, kemudian absorbansi dari filtratnya diukur dengan spektrofotometer UV-Vis pada $\lambda_{\max }$ metilen biru.

\section{Penentuan Luas Permukaan Batang Gumitir}

Sebanyak $1 \mathrm{~g}$ sampel arang aktif batang gumitir dimasukkan ke dalam Erlenmeyer 250 $\mathrm{mL}$ dengan menggunakan pengaduk magnet dengan waktu kontak dengan metilen biru yang bervariasi yaitu $5,10,15,20,40$ dan 60 menit. Larutan hasil pengadukan disaring dan filtratnya dianalisis menggunakan spektrofotometer UV-Vis pada panjang gelombang maksimum larutan metilen biru $664,60 \mathrm{~nm}$.

\section{Penentuan Keasaman Permukaan}

Sebanyak $1 \mathrm{~g}$ sampel arang aktif batang gumitir dimasukkan ke dalam Erlenmeyer 250 $\mathrm{mL}$ kemudian ditambahkan 15,0 $\mathrm{mL}$ larutan $\mathrm{NaOH} 0,1 \mathrm{M}$ sambil diaduk dengan pengaduk magnet selama 15 menit, lalu ditambahkan sebanyak 3-4 tetes indikator phenolphtalein $1 \%(\mathrm{~b} / \mathrm{v})$. Campuran dititrasi dengan larutan $\mathrm{HCl} 0,1 \mathrm{M}$ sampai terjadi perubahan warna dari merah muda menjadi tidak berwarna. Volume $\mathrm{HCl}$ yang digunakan dalam titrasi dicatat dengan teliti. 


\section{Analisis Gugus Fungsi}

Arang aktif yang menunjukkan karakteristik terbaik, dianalisis spektra inframerahnya sehingga dapat diketahui gugus-gugus fungsinya. Analisis spektroskopi inframerah dalam penelitian ini menggunakan spektrofotometer Shimadzu IRPrestige-21.

\section{HASIL DAN PEMBAHASAN}

\section{Kadar Air}

Prinsip dalam penentuan kadar air yang dilakukan pada penelitian ini yaitu dengan pemanasan pada suhu di atas $100^{\circ} \mathrm{C}$ selama 4 jam sehingga tercapai massa konstan. Hasil penentuan kadar air arang aktif dan arang tanpa aktivasi bisa dilihat pada tabel dibawah ini:

Tabel 1. Kadar Air Arang Aktif

\begin{tabular}{cc}
\hline Jumlah mol ZnCl & Kadar Air (\%) \\
\hline $0 \mathrm{~mol}$ & $8,00 \pm$ \\
$0,02 \mathrm{~mol}$ & $6,66 \pm 0,57$ \\
$0,05 \mathrm{~mol}$ & $6,33 \pm 0,57$ \\
$0,1 \mathrm{~mol}$ & $5,00 \pm$ \\
$0,2 \mathrm{~mol}$ & $6,66 \pm 0,57$ \\
$0,3 \mathrm{~mol}$ & $7,00 \pm$ \\
\hline
\end{tabular}

Menurut SNI 06 - 3730 - 1995 tentang arang aktif teknis, arang aktif dalam bentuk serbuk memiliki kadar air maksimal $15 \%$. Hasil penentuan kadar air yang ditunjukkan pada tabel di atas, menunjukkan bahwa arang aktif yang dibuat dengan berbagai jumlah mol $\mathrm{ZnCl}_{2}$ dalam penelitian ini memenuhi baku mutu kadar air arang aktif. Kadar air yang ditunjukkan oleh arang aktif dalam penelitian ini lebih kecil dibandingkan dengan arang yang tidak diaktivasi yaitu sebesar $8,00 \%$.

\section{Kadar Zat Mudah Menguap}

Prinsip dalam penentuan kadar zat mudah menguap pada peneltian ini adalah pemanasan pada suhu $900^{\circ} \mathrm{C}$ selama 15 menit, sehingga diperoleh berat konstan. Kadar zat mudah menguap ditentukan untuk mengetahui kandungan senyawa yang belum menguap pada proses karrbonisasi dan aktivasi. Hasil penentuan kadar zat mudah menguap arang aktif dan arang tanpa aktivasi dapat dilihat pada Tabel 2 berikut ini:
Tabel 2. Kadar Zat Mudah Menguap Arang Aktif

\begin{tabular}{cc}
\hline $\begin{array}{c}\text { Jumlah mol } \\
\mathrm{ZnCl}_{2}\end{array}$ & $\begin{array}{c}\text { Kadar Zat Mudah } \\
\text { Menguap }(\%)\end{array}$ \\
\hline $0 \mathrm{~mol}$ & $30,79 \pm 1,25$ \\
$0,02 \mathrm{~mol}$ & $21,07 \pm 0,74$ \\
$0,05 \mathrm{~mol}$ & $12,09 \pm 0,58$ \\
$0,1 \mathrm{~mol}$ & $7,36 \pm 1,05$ \\
$0,2 \mathrm{~mol}$ & $21,78 \pm 0,48$ \\
$0,3 \mathrm{~mol}$ & $17,19 \pm 1,86$ \\
\hline
\end{tabular}

Semakin tinggi kadar zat mudah menguap dari arang aktif,maka akan semakin menurun mutu arang aktif tersebut. Hal ini disebabkan karena senyawa-senyawa stabil yang terkandung dalam arang akan menutupi pori-porinya. Dari tabel diatas, dapat dikatakan bahwa arang tanpa aktivasi tidak memenuhi baku mutu. Menurut SNI 06 - 3730 - 1995 tentang arang aktif teknis, arang aktif dalam bentuk serbuk yang baik memiliki kadar zat mudah menguap maksimal sebesar $25 \%$. Oleh sebab itu, arang yang diaktivasi $\mathrm{ZnCl}_{2}$ dengan berbagai jumlah mol telah memenuhi baku mutu arang aktif, dengan kadar zat mudah menguap paling tinggi pada konsentrasi 0,2 mmol sebesar $21,78 \%$ dan paling rendah pada konsentrasi 0,1 mol sebesar 7,36\%.

\section{Kadar Abu Total}

Arang aktif yang terbuat dari bahan alam tidak hanya mengandung senyawa karbon saja, akan tetapi mengandung beberapa mineral. Sebagian mineral ini akan hilang saat proses karbonisasi dan aktivasi, sebagian lainnya akan tertinggal dalam arang aktif. Penentuan kadar abu total dalam penelitian ini bertujuan untuk mengetahui kandungan oksida logam dalam arang aktif. Kadar abu total arang aktif merupakan sisa yang tertinggal pada saat arang dibakar pada suhu $600^{\circ} \mathrm{C}-900^{\circ} \mathrm{C}$ selama 3 - 16 jam (Jankowska et al., 1991). Hasil penentuan kadar abu total arang aktif dan arang tanpa aktivasi dapat dilihat pada Tabel 3 .

Tabel 3. Kadar Abu Total Arang Aktif

\begin{tabular}{cc}
\hline Jumlah mol & Kadar Abu Total (\%) \\
$\mathrm{ZnCl}_{2}$ & \\
\hline $0 \mathrm{~mol}$ & $19,66 \pm 1,52$ \\
$0,02 \mathrm{~mol}$ & $9,33 \pm 0,57$ \\
$0,05 \mathrm{~mol}$ & $9,66 \pm 1,15$ \\
$0,1 \mathrm{~mol}$ & $8,33 \pm 0,57$ \\
$0,2 \mathrm{~mol}$ & $10,00 \pm 0,00$ \\
$0,3 \mathrm{~mol}$ & $10,33 \pm 0,57$ \\
\hline
\end{tabular}


Menurut SNI 06 - 3730 - 1995 tentang arang aktif teknis, arang aktif dalam bentuk serbuk memiliki kadar abu total maksimal sebesar 10\%. Dengan demikian, kadar abu total dalam arang aktif yang dibuat dengan berbagai jumlah mol $\mathrm{ZnCl}_{2}$ dalam penelitian ini sudah memenuhi baku mutu kadar abu total arang aktif, kecuali pada konsentrasi $0,3 \mathrm{~mol}$ memiliki kadar abu total lebih dari $10 \%$ yaitu sebesar 10,33\%. Arang aktif pada penelitian ini memiliki kadar abu total yang lebih rendah dibandingkan dengan arang tanpa aktivasi yaitu $19,66 \%$.

\section{Kadar Karbon Terikat}

Penentuan kadar karbon terikat pada penelitian ini berfungsi untuk mengetahui kadar karbon murni yang terkandung dalam arang aktif. Fraksi karbon dalam arang aktif merupakan hasil dari proses pengarangan selain air, abu, dan zat - zat mudah menguap, sehingga kadar karbon dapat ditentukan melalui selisih presentase total dengan jumlah presentase kadar air, kadar zat mudah menguap dan kadar abu dari arang aktif (Sudrajat dan Pari, 2011). Hasil penentuan kada karbon terikat arang aktif dan arang tanapa aktivasi dapat dilihat pada Tabel 4.

Tabel 4. Kadar Karbon Terikat Arang Aktif

\begin{tabular}{cc}
\hline $\begin{array}{c}\text { Jumlah mol } \\
\mathrm{ZnCl}_{2}\end{array}$ & $\begin{array}{c}\text { Kadar Karbon } \\
\text { Terikat }(\%)\end{array}$ \\
\hline $0 \mathrm{~mol}$ & 41,54 \\
$0,02 \mathrm{~mol}$ & 62,93 \\
$0,05 \mathrm{~mol}$ & 71,90 \\
$0,1 \mathrm{~mol}$ & 79,30 \\
$0,2 \mathrm{~mol}$ & 61,55 \\
$0,3 \mathrm{~mol}$ & 65,47 \\
\hline
\end{tabular}

Menurut SNI 06 - 3730 - 1995 tentang arang aktif teknis, arang aktif dalam bentuk serbuk yang baik memiliki kadar karbon minimal 65\%. Berdasarkan tabel di atas arang yang diaktivasi dengan $\mathrm{ZnCl}_{2}$ secara umum sudah memenuhi baku mutu arang aktif, sedangkan untuk arang tanpa aktivasi memiliki kadar karbon yang tidak memenuhi baku mutu arang aktif yaitu sebesar $41,54 \%$.

\section{Daya Serap Terhadap Iod Arang Aktif}

Uji iodium merupakan salah satu parameter untuk mengetahui kemampuan karbon aktif dalam menyerap molekul-molekul dengan massa molekul kecil. Pada proses penyerapan ini molekul-molekul iodium masuk dan mengisi pori-pori karbon aktif. Penentuan daya serap terhadap iod oleh arang aktif, menggunakan metode titrasi iodometri. Daya serap iodin diperoleh dari analisis filtrat campuran iodin dan arang aktif. Analisis dilakukan dengan titrasi iodometri lalu dihitung daya serap arang aktif terhadap larutan iodin dalam $\mathrm{mg} / \mathrm{gram}$. Hasil penentuan daya serap terhada iod arang aktif dan arang tanpa aktivasi dapat dilihat pada Tabel 5 .

Tabel 5. Daya Serap Terhadap Iod Arang

\begin{tabular}{cc} 
Aktif & \\
\hline Jumlah mol ZnCl & $\begin{array}{c}\text { Daya Serap Iodin } \\
(\mathrm{mg} / \mathrm{g})\end{array}$ \\
\hline $0 \mathrm{~mol}$ & $740,4114 \pm 1,52$ \\
$0,02 \mathrm{~mol}$ & $783,6066 \pm 0,86$ \\
$0,05 \mathrm{~mol}$ & $785,1134 \pm 0,50$ \\
$0,1 \mathrm{~mol}$ & $788,1271 \pm 1,73$ \\
$0,2 \mathrm{~mol}$ & $787,6248 \pm 1,73$ \\
$0,3 \mathrm{~mol}$ & $781,0951 \pm$ \\
\hline
\end{tabular}

Daya serap iodium biasanya dijadikan indikator utama dalam menentukan kualitas arang aktif. Data yang diperoleh pada arang yang diaktivasi dengan $\mathrm{ZnCl} 2$ telah memenuhi baku mutu arang aktif dengan daya serap iod tertinggi pada penambahan $\mathrm{ZnCl} 2 \quad 0,1 \mathrm{~mol}$ sebesar $788,1271 \mathrm{mg} / \mathrm{g}$ dan daya serap iod terendah pada penambahan $\mathrm{ZnCl} 20,3 \mathrm{~mol}$ yaitu sebesar 781,0951 mg/g, sedangkan untuk arang tanpa aktivasi tidak memenuhi standar baku mutu arang aktif, karena daya serap terhadap iod yg dihasilkan sebesar 740,4114 $\mathrm{mg} / \mathrm{g}$. Menurut SNI $06-3730-1995$ tentang arang aktif teknis daya serap terhadap iod arang aktif dalam bentuk serbuk minimal 750 $\mathrm{mg}$ iodin/gram arang aktif.

\section{Daya Serap Terhadap Metilen Biru}

Penentuan daya serap terhadap metilen biru bertujuan untuk mengetahui luas permukaan dari arang aktif, serta mengetahui kemampuan arang aktif dalam menyerap larutan berwarna (Jankowska et al., 1991). Panjang gelombang maksimum dari metilen biru yang digunakan pada penelitian ini adalah 664,60 nm. Daya serap metilen biru menurut SNI 06-3730-1995 tentang arang aktif teknis minimal sebesar $120 \mathrm{mg} / \mathrm{g}$. Meningkatnya luas permukaan arang aktif disebabkan karena aktivator $\mathrm{ZnCl} 2$ mampu mengurangi pengotorpengotor yang menyumbat pori-pori arang 
sehingga menyebabkan pori-pori arang aktif menjadi lebih terbuka serta memberikan gugus aktif yang mampu memperbesar daya serap arang terhadap metilen biru (Sudrajat dan Pari, 2011). Hasil penentuan daya serap terhadap metilen biru arang aktif dan arang tanpa aktivasi dapat dilihat pada Tabel 6 .

Tabel 6. Hasil Penentuan Daya Serap Terhadap Metilen Biru

\begin{tabular}{cc}
\hline Jumlah mol & Daya Serap Metilen \\
$\mathrm{ZnCl}_{2}$ & Biru mg/g \\
\hline $0 \mathrm{~mol}$ & $143,6504 \pm 3,49$ \\
$0,02 \mathrm{~mol}$ & $65,0188 \pm 14,78$ \\
$0,05 \mathrm{~mol}$ & $227,4763 \pm 7,33$ \\
$0,1 \mathrm{~mol}$ & $260,7917 \pm 1,11$ \\
$0,2 \mathrm{~mol}$ & $176,6076 \pm 5,79$ \\
$0,3 \mathrm{~mol}$ & $163,1739 \pm 4,47$ \\
\hline
\end{tabular}

\section{Luas Permukaan Arang Aktif}

Luas permukaan merupakan salah satu karakter fisik yang memiliki peranan penting dalam proses adsorpsi. Banyaknya zat yang mampu teradsorpsi oleh adsorben salah satunya ditentukan oleh luas permukaan, yaitu semakin luas permukaan adsorben semakin besar kapasitas adsorpsinya. Analisis luas permukaan dalam penelitian ini dilakukan dengan menggunakan metode metilen biru. Banyaknya metilen biru yang dapat diadsorpsi akan sebanding dengan luas permukaan arang aktif tersebut. Panjang gelombang metilen biru yang digunakan dalam penelitian ini adalah panjang gelombang maksimum yaitu 664,60 $\mathrm{nm}$. Hasil dari penentuan luas permukaan arang aktif dan arang tanpa aktivasi dapat dilihat pada Tabel 7.

Tabel 7. Luas Permukaan Arang yang diaktivasi dengan $\mathrm{ZnCl}_{2} \quad 0,1 \mathrm{~mol}$ dan Arang Tanpa Aktivasi

\begin{tabular}{cc}
\hline Sampel & $\mathrm{S}\left(\mathrm{m}^{2} / \mathrm{g}\right)$ \\
\hline Arang Aktif & 677,6270 \\
Arang Tanpa Aktifasi & 511,2394 \\
\hline
\end{tabular}

Tabel 7. menunjukkan bahwa luas permukaan arang batang gumitir yang diaktivasi dengan $\mathrm{ZnCl} 2$ 0,1 mol lebih besar dibandingkan dengan luas permukaan arang batang gumitir tanpa aktivasi. Arang aktif mempunyai luas permukaan 677,6270 /g lebih besar dari arang batang gumitir yang tidak diaktivasi. Kenaikan luas permukaan arang aktif ini disebabkan karena aktivator $\mathrm{ZnCl}_{2}$ dapat melarutkan pengotor-pengotor yang menutupi pori. Pengotor pada pori dapat menghambat proses adsorpsi, sehingga dengan melarutnya pengotor dari arang maka poriporinya menjadi lebih terbuka dan pada akhirnya menambah situs aktif. Selain itu penggunaan aktivator $\mathrm{ZnCl} 2$ dapat membuat pori dari arang menjadi homogen.

\section{Jumlah Situs Aktif dan Keasaman Permukaan \\ Penentuan keasaman permukaan} bertujuan untuk mengetahui jumlah mmol dari situs asam yang terikat pada biosorben atau adsorben per satu gramnya. Penentuan jumlah situs aktif dilakukan dengan cara kuantitatif menggunakan metode titrimetri yaitu dengan titrasi asam basa, situs-situs asam dari arang batang gumitir direaksikan dengan $\mathrm{NaOH}$ berlebih dan sisa $\mathrm{OH}$ - yang tidak bereaksi dengan situs-situs asam dari adsorben dititrasi dengan menggunakan $\mathrm{HCl} 0,1 \mathrm{M}$. Jumlah situs aktif ini dihitung dari selisih jumlah $\mathrm{HCl}$ untuk mentitrasi blanko dengan jumlah $\mathrm{HCl}$ untuk titrasi adsorben. Hasil penentuan jumlah situs aktif dan keasaman permukaan dapat dilihat pada Tabel 8.

Tabel 8. Keasaman Permukaan Arang Aktif

\begin{tabular}{lcc}
\hline $\begin{array}{c}\text { Jumlah } \\
\text { mol } \\
\mathrm{ZnCl}_{2}\end{array}$ & Kal (mmol/gram) & $\begin{array}{c}\text { Jumlah Situs } \\
\text { Aktif } \\
\text { (molekul/gram }\end{array}$ \\
\hline $0 \mathrm{~mol}$ & $0,2251 \pm 0,2249$ & $1,3552 \times 10^{20}$ \\
0,02 & $0,2867 \pm 0,0028$ & $1,7265 \times 10^{20}$ \\
mol & & \\
0,05 & $0,2483 \pm 0,0154$ & $1,4952 \times 10^{20}$ \\
mol & & \\
$0,1 \mathrm{~mol}$ & $0,3396 \pm 0,0028$ & $2,0450 \times 10^{20}$ \\
$0,2 \mathrm{~mol}$ & $0,1970 \pm 0,0048$ & $1,1863 \times 10^{20}$ \\
$0,3 \mathrm{~mol}$ & $0,3364 \pm 0,0000$ & $2,0258 \times 10^{20}$ \\
\hline
\end{tabular}

\section{Analisis Gugus Fungsi}

Identifikasi gugus fungsi dilakukan terhadap arang tanpa aktivasi dan arang yang diaktivasi dengan $\mathrm{ZnCl}_{2}$ dengan menggunakan instrumen Spektrofotometer FTIR. Gugus fungsi merupakan gugus aktif yang dimiliki oleh arang aktif. Gugus-gugus yang terdapat pada arang akif dapat memberikan pengaruh pada karakter yang dimiliki oleh arang aktif tersebut. Data spektrum inframerah yang dihasilkan dari arang tanpa aktivasi dan arang aktif dapat dilihat pada tabel berikut ini. 
Pembuatan dan Karakterisasi Arang Aktif Dari Batang Limbah Tanaman Gumitir dengan Aktivator $\mathrm{Zncl}_{2}$

E. Sahara, D. E. Permatasaari, I W. Suarsa

Tabel 9. Data Spektrum Inframerah Arang Tanpa Aktivasi dan Arang Aktif

\begin{tabular}{|c|c|c|c|}
\hline \multicolumn{2}{|c|}{$\begin{array}{l}\text { Bilangan Gelombang } \\
\left(\mathrm{cm}^{-1}\right)\end{array}$} & \multicolumn{2}{|c|}{ Gugus Fungsi } \\
\hline Arang & Arang & Arang & Arang \\
\hline $\begin{array}{c}\text { Tanpa } \\
\text { aktivasi }\end{array}$ & Aktif & $\begin{array}{c}\text { Tanpa } \\
\text { aktivasi }\end{array}$ & Aktif \\
\hline 3373,50 & 410,84 & $-\mathrm{OH}$ asam & $\begin{array}{c}\text { C-H luar } \\
\text { bidang }\end{array}$ \\
\hline 2960,73 & 887,26 & -CH alifatik & $\begin{array}{c}-\mathrm{CH}_{2} \\
\text { luar } \\
\text { bidang }\end{array}$ \\
\hline 2931,80 & 1394,53 & -CH alifatik & $\mathrm{CH}_{3}$ \\
\hline 1379,10 & 2218,14 & -CH alifatik & $\begin{array}{c}\mathrm{C}=\mathrm{C} \\
\text { alkuna }\end{array}$ \\
\hline & 1695,43 & & $\begin{array}{l}\mathrm{C}=\mathrm{O} \\
\text { aldehid }\end{array}$ \\
\hline & 2835,36 & & $\mathrm{COOH}$ \\
\hline & 3226,91 & & $\begin{array}{c}\mathrm{OH} \\
\text { terikat }\end{array}$ \\
\hline & 3591,46 & & $\begin{array}{c}\mathrm{OH} \\
\text { terikat }\end{array}$ \\
\hline
\end{tabular}

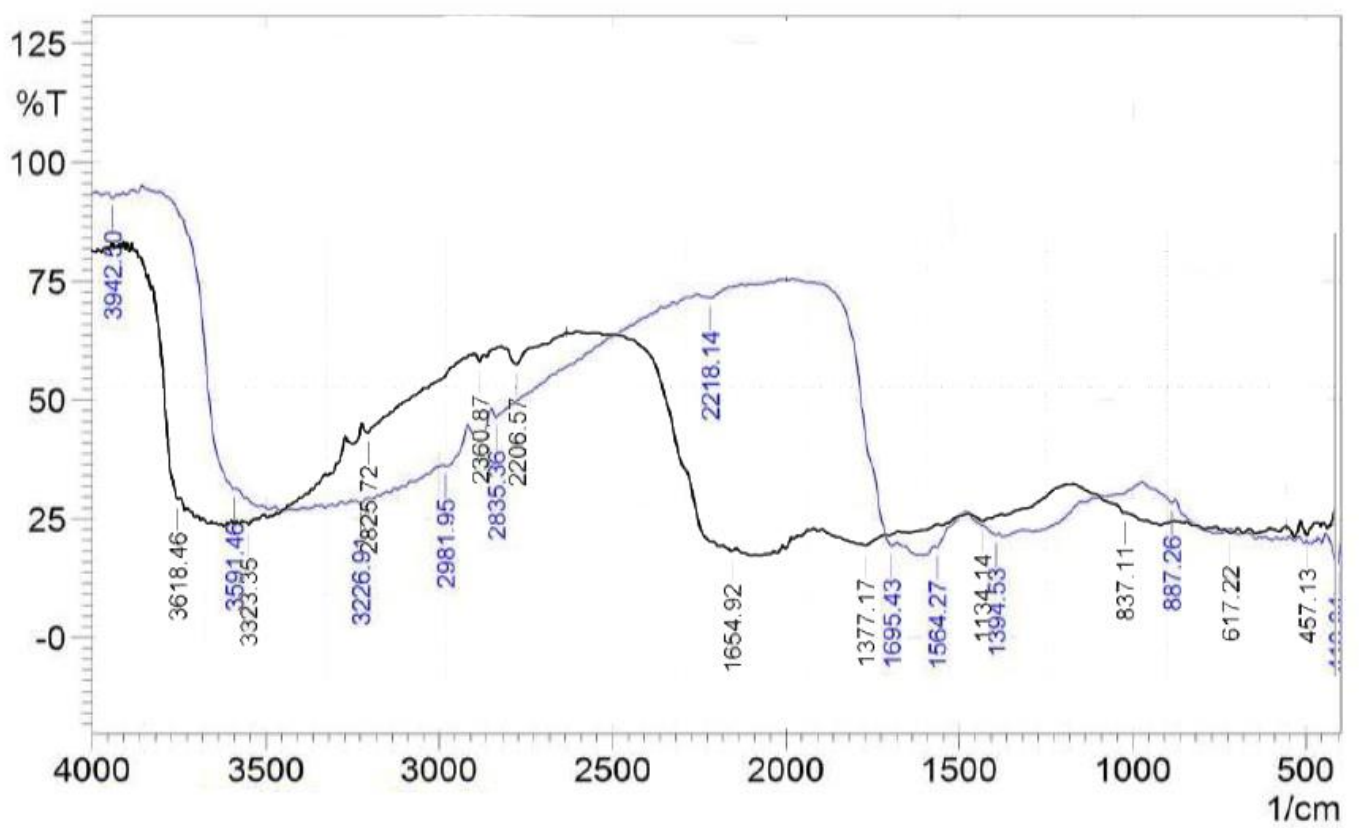

Gambar 1. Spektra inframerah arang tanpa aktif dan arang aktif 


\section{SIMPULAN DAN SARAN}

\section{Simpulan}

Karakterisasi arang aktif yang dihasilkan dengan aktivator $\mathrm{ZnCl}_{2}$ secara umum sudah memenuhi baku mutu sesuai SNI 06-3730-1995 tentang arang aktif teknis. Penambahan $\mathrm{ZnCl}_{2}$ dengan perbandingan arang 1 : 0,1 mol menghasilkan arang aktif dengan karakteristik yang terbaik yaitu: kadar air $5,00 \%$, kadar abu 8,33 \%, kadar zat mudah menguap pada pemanasan $950^{\circ} \mathrm{C}$ sebesar $7,36 \%$, daya serap terhadap iod sebesar 788,1271 $\mathrm{mg} / \mathrm{g}$, daya serap terhadap metilen biru sebesar 260,7917 $\mathrm{mg} / \mathrm{g}$, mempunyai luas permukaan sebesar $677,6270 \mathrm{~m}^{2} / \mathrm{g}$ dan keasaman permukaan sebesar 0,3396 mmol/gram. Arang aktif ini mempunyai gugus fungsi $\mathrm{O}-\mathrm{H}, \mathrm{COOH}, \mathrm{C}-$ $\mathrm{O}$ aldehid, C-C alkuna dan $\mathrm{C}-\mathrm{H}$.

\section{Saran}

Berdasarkan hasil penelitian yang telah dilakukan, maka dapat disarankan agar dilakukan penelitian lebih lanjut mengenai kemampuan arang aktif dari batang tanaman gumitir yang diaktivasi dengan $\mathrm{ZnCl}_{2}$ sebagai adsorben logam berat ataupun senyawa organik dalam limbah cair.

\section{DAFTAR PUSTAKA}

Basu, P., 2006, Combustion and Gasification In Fluidized Beds, CRC, New York.

Cooney, D.O., 1980, Activated Charcoal,Antidotal, and Other Medical Uses, Marcel Dekker, New York.

Esterlita, M. O., dan Herlina N., 2015, Pengaruh Penambahan Aktivator $\mathrm{ZnCl}_{2}$, $\mathrm{KOH}$, dan $\mathrm{H}_{3} \mathrm{PO}_{4}$ dalam Pembuatan Karbon Aktif dari Pelepah Aren (Arenga Pinnata), Jurnal Teknik Kimia USU, Vol. 4, No. 1.
Jamilatun, S., Intan D.I., dan Elza N.P., 2014, Karakteristik Arang Aktif dari Tempurung Kelapa dengan Pengaktivasi $\mathrm{H}_{2} \mathrm{SO}_{4}$ Variasi Suhu dan Waktu, J. Simposium Nasional Teknologi Terapan, 2:31-38.

Jankowska, H., A, S. dan Choma J., 1991, Active Carbon, Horwood, London.

Sahara, E., Kartini Ni P. W., Sibarani, J., 2017, Pemanfaatan Arang Aktif dari Limbah Tanaman Gumitir (Tagetes erecta) Teraktivasi Asam Fosfat $\left(\mathrm{H}_{3} \mathrm{PO}_{4}\right)$ sebagai Adsorben Ion $\mathrm{Pb}^{2+}$ dan $\mathrm{Cu}^{2+}$ dalam Larutan, Cakra Kimia [Indonesia E-Journal of Applied Chemistry], 5(2): 67-74.

Pambayun G. S., Remigius Y. E., Yulianto., M. Rachimoellah., dan Endah M. M. Endah., 2013, Pembuatan Karbon Aktif dari Arang Tempurung Kelapa dengan Aktivator $\mathrm{ZnCl}_{2}$ dan $\mathrm{Na}_{2} \mathrm{CO}_{3}$ sebagai Adsorben untuk Mengurangi Kadar Fenol dalam Air Limbah, Jurnal Teknik Kimia ITS Vol. 2, No. 1.

Radiansyah, D., dan Supardan M. D., 2014, Optimasi Proses Pembuatan Karbon Aktif dari Ampas Bubuk Kopi Menggunakan Aktivator $\mathrm{ZnCl}_{2}$, Jurnal Teknologi dan Industri Pertanian Indonesia, Vol. 6 (3) : 1-5.

Sahara, E., Sulihingtyas, W. D., dan Mahardika, I. P. A. S., 2017, Pembuatan dan Karakteristik Arang Aktif dari Batang Tanaman Gumitir (Tagetes erecta) Yang Diaktivasi dengan $\mathrm{H}_{3} \mathrm{PO}_{4}$, Cakra Kimia [ Indonesia E-Journal of Applied Chemistry ], 11 (1) : 1-9.

Sahara, E., Manuaba, I. B. P., dan Dahliani, N. K., 2017, Pembuatan dan Karakteristik Arang Aktif dari Batang Tanaman Gumitir (Tagetes erecta) dengan Aktivator $\mathrm{NaOH}$, Jurnal Kimia [Journal of Chemistry], 11 (2) : 174-180. 
Siaka, M., Febriyanti, Ni. P. D., Sahara, E., dan Negara, M., S., 2016, Pembuatan dan Karakterisasi Arang dari Batang Tanaman Gumitir (Tagetes erecta) pada Berbagai Suhu dan Waktu Pirolisis, Cakra Kimia [Indonesia EJournal of Applied Chemistry], 4(2): 168-177.

Siaka, M., Putri, Ni. P. D. O., dan Suarsa, W. S., 2017, Pemanfaatan Arang Aktif dari Batang Tanaman Gumitir (Tagetes erecta) sebagau Adsorben Logam Berat $\mathrm{Pb}(\mathrm{II})$ dan $\mathrm{Cd}(\mathrm{II})$ dengan Aktivator $\mathrm{NaOH}$, Cakra Kimia [Indonesia E-Journal of Applied Chemistry], 5(2): 120-130
SNI, 1995, SNI 06-3730-1995: Arang Aktif Teknis, Badan Standarisasi Nasional, Jakarta.

Sudrajat, R. dan Pari, G., 2011, Arang Aktif, Teknologi Pengolahan dan Masa Depannya, Badan Penelitian dan Pengembangan Kehutanan, Jakarta 